\title{
ANALYSIS OF FACTORS AFFECTING MANGO MARKET SUPPLY IN GOMMA DISTRICT, SOUTHWEST ETHIOPIA
}

\author{
Yordanos Teka ${ }^{1}$, Hash Malin ${ }^{2}$ and Alemayehu Oljira ${ }^{3}$ \\ ${ }^{1}$ Junior Credit Officer at Development Bank of Ethiopia Bongo Branch Office \\ ${ }^{2}$ Food Security Expert at Somali Regional State, Ethiopia \\ ${ }^{3}$ Lecturer at Jimma University College of Agriculture and Veterinary Medicine Department of Agricultural \\ Economics and Agribusiness Management \\ *corresponding author: alemayehuoljira82@gmail.com
}

\begin{abstract}
This study is designed to analyze factors affecting mango market supply and identify the existing market channels in Gomma district, Southwest Ethiopia. Descriptive statistics such as mean, standard deviation $\&$ frequencies and multiple linear regressions have been used to analyze the data collected from mango market actors. The study identified seven potential mango market channels in the study area. Producer-RetailerConsumer marketing channel was identified to be the first and most important mango marketing channel in the study area. It represented $26 \%$ of the total mango marketed during the survey period. The result from multiple linear regressions model indicates that from the total of ten independent variables five variables such as quantity of mango tree owned, age, education and access to market information were identified as factors affecting volume of mango market supply. Their magnitude, relationship with quantity of mango market supply and interpretations are given in results and discussion section. Finally, possible policy recommendations have been suggested.
\end{abstract}

Keywords: Multiple Linear Regressions; Market Supply; Mango, Market Channel, Gomma District

http://dx.doi.org/10.21776/ub.agrise.2019.019.3.7

Received 06 April 2019

Accepted 05 August 2019

Available online 25 August 2019

\section{INTRODUCTION}

Fresh tropical fruit production has risen by $7 \%$ in world market annually since 1997; and the bulk of theses fruits $(98 \%)$ are grown in developing countries. The latest figure shows that pineapple accounts for $44 \%$ of the total traded volume, followed by mango (27\%), avocado (12\%), and papaya (7\%) (Yeshitila \& Nessel, 2004). The main reason for increase in demand of tropical fruit is the growing familiarity of consumers with tropical fruits; their tastes, nutritional value and cooking qualities. Promotion of horticultural crops production and trade has recently become one of the key objectives of the developing countries (Lumpkin et al., 2005). IFADS' regional strategy for Sub-Saharan Africa focuses on enhancing the income of smallholders within the context of trade liberalization where smallholders' production and marketing of fruits and vegetables is a key focus (IFAD, 2003)

Ethiopian economy is mainly dominated by agriculture where $40 \%$ of the national GDP, $90 \%$ of export earnings and $85 \%$ of employment opportunity are contributed by the sector (World Bank, 2004). South West Ethiopia particularly Jimma Zone is endowed with diverse natural resources and has the capacity to grow different 
annual and perennial crops such as coffee, avocado, mango, orange and papaya. Fruit production is mainly for marketing albeit agricultural production is very fragmented and uncoordinated where all farmers produce similar types of crops resulting in glut especially in harvest season.

The production potential of fruits is not widely and evenly distributed across the various regions of the country. The cultivation is also seasonal and the supply is scanty and volatile even in areas where irrigation is possible. The knowledge gap on fruit production techniques and processing technology is wide. Also knowledge of domestic consumers of the benefits of fruits is confined to very few verities. Hence, domestic demand with the exception of few widely known tropical fruits is generally small (Seifu, 2003).

Various studies show that people generally consume fruits and vegetables on a daily bases, without considering them as a basic food item. These factors have already affected the growth and expansion of the fruit sub-sector in Ethiopia. Lack of concerned public support, scanty of market information, poor understanding of the market works; and lack of systematic documented knowledge are main threats that hampered the benefits from the sector (Tsegaye et al., 2009). The existing income generating capacity of fruits as compared to its immense potentials at the macro and micro level is not encouraging. For example, from the total 3.5 million quintals of fruits produced in the country, only less than $2 \%$ is exported (Joosten, 2007; MOARD, 2005). The nature of the product on one hand and lack of organized marketing system on the other hand often resulted in low producers' price.

Development needs of fruits in general and that of mango in particular is poorly addressed in Ethiopia. But these days efforts have been stepped up to improve and support the sector. With this line, the current growth and transformation plan of Ethiopia (GTP) prioritizes intensive production and commercialization of horticulture as a sector for attention. Thus the development policy initiates the need to accelerate and lucid the transformation of the subsector from the subsistence to business and market oriented agriculture. But the existing constraints of post harvest and market infrastructures such as: packaging, pre cooling, warehousing, cold storage, pre-package and

Agricultural Socio-Economics Journal distribution have played their deterring role on trade and consumption of fruits in the country (Seifu,2003). Furthermore, fruit marketing channels, and their characteristics have been not studied. Therefore, the current study is designed to identify the existing marketing channels and factors affecting mango market supply in Gomma district, southwest Ethiopia.

\section{RESEARCH METHODS}

Gomma district is one of the 17 districts in Jimma Zone Oromia Regional State, Ethiopia. It extends between $7^{0} 40^{\prime}-8^{0} 04^{\prime}$ north latitudes and $36^{0} 17^{\prime}$ $36^{0} 46^{\prime}$ east longitudes. The district is located 390 $\mathrm{km}$ South West of Addis Ababa and about $50 \mathrm{~km}$ west of Jimma town. There are 36 rural kebeles and 3 urban kebeles in Gomma district. The number of agricultural households in the district is 45,567 from which 35,533 are male headed and 10,034, female headed. The total population of the district was 216,662 from which 110,448 are males and 106,174 females (CSA, 2008). It is the second most densely populated district in the zone with two coffee state farms which cover an area of 2704 ha (IPMS, 2007). Gomma district is one of the foundations and origin of coffee Arabica where the life of the people in the district is directly or indirectly connected with Coffee $\&$ fruit production (Profile of Gomma district /Wikipedia) (IPMS, 2007). The district has a total surface area of $936.58 \mathrm{Km}^{2}$ (993657.72 hectare) that accounted 4.8 $\%$ of the total area of Jimma Zone. Agaro town is the capital of the district.

\section{Sources and Types of Data}

We have used both primary and secondary data for the study. Primary data was collected using structured questionnaire through face to face or direct interview with respondents. While secondary data was gathered through reviewing and examination of documents, annual reports and records of published and unpublished documents. Both qualitative and quantitative data were used.

\section{Sample size determination}

Two stage sampling procedure was used to select the sample respondents. In the first stage two kebeles namely Bulbul and Homo Bako were randomly selected out of the total 36 mango producer rural kebeles. The total numbers of mango 
producer households in Bulbul and Bako kebels were 158 and 110 respectively. Using Yamane (1957) sample proportion formula 43 and 30 sample households have been selected from the two kebeles respectively.

Therefore, 73 sample households have been interviewed.

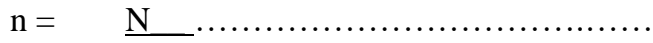

$$
\begin{aligned}
& 1+\mathrm{N}\left(\mathrm{e}^{2}\right)
\end{aligned}
$$

Where:

$\mathrm{n}=$ sample size

$\mathrm{N}=$ total number of households

$\mathrm{e}=$ margin of error $(10 \%)$

The sites for the trader surveys were market town where large number of mango traders available. On the basis of flow of mango, four markets namely Jimma, Agaro, Lemi and Choche were selected purposively because they are the main mango marketing sites in the study area. As a result 15 mango traders were selected by systematic random sampling technique.

\section{Data Analysis}

Data was analyzed using both descriptive statics and econometric model. Descriptive statistics such as mean, standard deviation and frequency were used to describe socioeconomic characteristics of respondents.

\section{Econometric Analysis}

Quantity of mango supplied to the market, measured in quintal is the dependent variable of the study. At the time of household survey, it was confirmed that about $95 \%$ of producers in the study area are mango market suppliers. Therefore, it is recommendable to use Ordinary Least Square Model to analyze factors affecting mango market supply. Following Green (2003), the multiple linear regression models are specified in a matrix notation as:

$$
Y_{i}=\beta X+U_{i} \ldots \ldots \ldots \ldots \ldots \ldots \ldots \ldots \ldots \ldots \ldots
$$

Where:

$Y_{i}=$ Value of mango supplied to the market

$B=$ a vector of estimated coefficient of the explanatory variables

$\mathrm{X}=$ a vector of explanatory variables

$\mathrm{Ui}=$ disturbance term

For the parameter estimates to be efficient, unbiased and consistent assumptions of linear regression model should hold true. Hence, multicollinearity, and heteroscedasticity detection tests were performed using appropriate test statistics.

\section{Variable definitions and working hypothesis}

The dependent variable of the study is volume of mango sold in the market while the independent variables are:

Sex of the respondents: It is a dummy variable taking 1 if male and 0 otherwise. It was assumed to have either positive or negative relationship with the volume of mango supplied to the market.

Education of household heads: It is a continuous variable measured in years of school. Farmers with better formal education can adopt new agricultural production and marketing practices than their counterparts and would increase marketable surplus. The literate the household head is the better would be the awareness of the farmer towards market participation and postharvest loss management. Therefore, this variable is expected to have positive coefficient.

Age: It is a continuous variable taken as one of the independent variables. The expected relationship of age with the volume of mango supplied to the market was positive. As farmers become older and older in age, he/she will have better knowledge and will decide to allocate more size of land for agricultural production and supply more to the market.

Family Size: This is a continuous variable assumed to have a positive relationship with the volume of mango market supply. The more the number of members in a household the more size of land allocated to agricultural production and market surplus. This is because family members are source of labor supply for agricultural activities.

Distance from development agents' office: It is a continuous variable refers to the distance between producers' home and development agents' office. The nearer a farmer is to the development agent the more frequent would be his/her chance to get an advice. Hence, the expected sign for this continuous variable measured in single feet hours was negative. As the farmer dwelled far from development agents' office the lesser would be the chance for extension contact and hence less knowledge, less land allocation and market supply. 
Access to credit: It is a dummy variable taking 1 if respondents have access to credit 0 otherwise. Credit helps farmers to purchase agricultural inputs to increase agricultural production. Therefore, this variable is assumed to have a positive relationship with the volume of mango supplied to the market.

Membership in Cooperatives: It is a dummy variable taking 1 if a given respondent is a member of producer or marketing cooperatives 0 otherwise. Farmers with membership in producer or marketing cooperatives are supposed to be in a better position to know the benefits of market participation. Therefore, it is hypothesized to have positive coefficient.

Access to market information: This is a dummy variable taking value of 1 if a respondent have access to market information 0 otherwise. It is assumed to have a positive relationship with the volume of mango supplied to the market.

Distance from the nearest market center: It is a continuous variable measured in a single feet hour. The nearer a farmer to a market center the more frequent would be he/she supply to the market. Hence, the expected sign for this variable is negative. As a farmer dwelled far away from the market center, the lesser would be the chance for market supply.

Quantity of mango tree owned by respondents: This is a continuous variable measured in a number of mango trees owned by respondents. If a given farmer has plenty of mango trees, he/she will harvest more and supply to the market. Therefore, this variable is assumed to have a positive relationship with the volume of mango supplied to the market.

\section{RESULTS AND DISCUSSION}

\section{Descriptive statistics}

As indicated in Table 1, out of the total interviewed mango producers $57.5 \%$ of them are male and the rest $42.4 \%$ were female respondents. This indicates that majority of mango producers in the study area are male headed households. From the total respondents $72.6 \%$ were illiterate and the remaining $27.39 \%$ were literate. The result indicates that mango producers in the study area are mainly illiterate suggesting that extension and training services needed to capacitate their skill gap. The marital statuses of the respondents in the study area are single (12.3\%), married (54.79\%), widowed $(17.8 \%)$ and the remaining $15 \%$ are divorced. As far as the religion of the respondents is concerned Muslims accounted for $45.2 \%$ and the remaining orthodox and Protestants accounts for $34.24 \%$ and $20.54 \%$ respectively.

Credit is an important service to access innovative technologies and output marketing. Even if one micro-finance and four commercial banks are available in the study area, only $55 \%$ of the total respondents received credit and the remaining $45 \%$ were not accessed credit services. From all respondents only about $47 \%$ of them have extension while the remaining $53 \%$ of the respondents reported that they had no extension contact. The study result indicates that extension service is largely in favor of other food crop production and is delivered unintentionally to fruits in the study area. This is in line with Carlson et al., (2008) who explained the current extension approach is in favor of cereals but not fruits. Thus, it has negatively affected the fruit production and marketing. Belay (2003) also indicated agricultural extension service has failed to bring major impact on productivity of fruits due to weak link between stakes and associate workloads of extension agents. Davis (2006) has also stated that dearth of extension service has led to poor linkage to support avocado industry.

From the total respondents only $44 \%$ of mango producers have access to market information and majority of producers $(56 \%)$ have no access to market information. The study indicates that colleague farmers are the first source of information followed by producers while traders, government extension workers and NGOs are second, third and fourth information sources respectively in the study area. The study shows that farmers get limited market information than traders with their own efforts. Owing to inequitable access to market information, large proportion of market power is captured by traders who have diversified information sources including: neighbors, fruit traders, personal observation and better access to mobile technology which favored traders to adverse risks of loss to this product. 
Table 1 Mango producers' characteristics for dummy and categorical variables

\begin{tabular}{lccr}
\hline \multicolumn{1}{c}{ Variable } & Category & Frequency & Percentage \\
\hline \multirow{3}{*}{ Education } & Male & 42 & 57.5 \\
& Female & 31 & 42.4 \\
\multirow{3}{*}{ Marital status } & literate & 20 & 27.39 \\
& Illiterate & 53 & 72.6 \\
& Single & 9 & 12.3 \\
& Married & 40 & 54.79 \\
& Widowed & 13 & 17.8 \\
Religion & Divorced & 11 & 15 \\
& Muslims & 33 & 45.2 \\
\multirow{3}{*}{ Mango producers' access to services } & 25 & 34.24 \\
Credit service & Orthodox & 15 & 20.54 \\
\multirow{2}{*}{ Extension service } & Protestant & & \\
\multirow{2}{*}{ Market Information } & & 40 & 55 \\
& Yes & 33 & 45 \\
& No & 34 & 47 \\
& Yes & 39 & 53 \\
& No & 32 & 44 \\
\hline
\end{tabular}

The average age of the sample households was 44.55 years (Table 2). This indicates that mango producers in the study area are within the productive age. The data result also indicates that average family size of mango producer household is 5.77. Large family size is a source of labor for agricultural production and increases volume of market supply. Average land holding of mango producers in the study area is 3.84 hectares. The average mango tree per farm was 7 . The average yield reported by producers was 3 quintal per tree where majority of the respondents reported 2-3 quintal per tree. A few respondents reported more than $400 \mathrm{~kg}$ per tree. The reported range of yield was less than other countries where the productivity ranges from 400 to $500 \mathrm{~kg}$ fruits per tree (5.5-33.1 tons/ha) depending on different factors such as variety, tree age, tree size, seasonal conditions, management and previous cropping history (Griesbach,2003, Tiwari and Baghel, 2014)

Table 2 Mango producers' characteristics for continuous variables

\begin{tabular}{lll}
\hline Variable & Mean & SD \\
\hline Age & 45.55 & 13.24 \\
Family size & 5.77 & 2.84 \\
Land size & 3.84 & 2.41 \\
Number of mango trees & 20 & 2.51 \\
Productivity per tree in quintal & 2.7 & 2.73 \\
\hline
\end{tabular}

\section{Mango marketing channel}

Mango marketing channels were constructed based on the data collected from the three mango markets (Figure 1). The study result revealed that there are 8 major mango marketing channels in the study area.

I. Producer $\rightarrow$ Retailer $\rightarrow$ Consumer
Channel: It represented $26 \%$ of the total mango marketed during the survey period. The channel was identified to be the first and most important mango marketing channel in the study area.

II. Producer $\longrightarrow$ Processor $\longrightarrow$ Consumer

Channel: It accounted for $13 \%$ of total mango marketed in the study area during the survey 
period. The channel was found to be the third important channel in the study area.

\section{Producer $\longrightarrow$ Rural assemblers $\longrightarrow$ Processor $\rightarrow$ Consumer}

Channel: It accounted for $7 \%$ of total mango marketed during the survey period. The channel was found to be the fourth and least important in study.

IV. Producer $\longrightarrow$ Wholesaler $\rightarrow$ Processor $\rightarrow$

Consumer

Channel: It accounted for $7 \%$ of total mango marketed during the survey period. The channel was found to be the fourth and least important in study area.

\section{Producer $\rightarrow$ Rural Assemblers $\rightarrow$ Wholesaler $\rightarrow$ Retailer $\rightarrow$ Consumer}

Channel: It represented $13 \%$ of total mango marketed during the survey period. The channel was found to be the third important marketing channel in study area.

\section{Producer $\rightarrow$ Wholesaler $\rightarrow$ Retailer $\rightarrow$ Consumer}

Channel: It accounted for $20 \%$ of total mango marketed during the survey period. The channel was found to be the second important in study area.

VII. Producer $\rightarrow$ Rural assemblers $\rightarrow$ Wholesaler Processor $\rightarrow$ Consumer

Channel: It represented $7 \%$ of total mango marketed during the survey period. The channel was found to be the fourth least important marketing channel in terms of volume and accompanied by large number of intermediaries in the market.

VIII. Producer $\rightarrow$ Consumer

Channel: It accounted for $7 \%$ of the total mango marketed. The channel is the fourth and least important mango marketing channel in the study area.

\section{Econometrics Model output}

More than $95 \%$ of mango producers in Gomma district are market participants. Therefore, Linear Regression Models were employed to identify factors affecting volume of mango market supply measured in quintals. For the parameter estimates to be efficient, unbiased and consistent assumptions of linear regression model should hold true. Hence, multicollinearity, and heteroscedasticity detection tests were performed using appropriate test statistics. The result for mean of VIF was 1.07. Therefore, Since VIF is less than 10, serious multicollinearity problems would not be suspected
(Table 4). Also, Breusch-pagan test was used to check for hetroscedasticity and the result showed that $p$-value of 0.09 indicating constant variance (Table 5). After the appropriate tests, the OLS regressions were run to identify the relationship between the independent and dependent variables. Based on the OLS estimation result, five variables were found to influence mango market supply (Table 6).

Quantity of mango tree owned: The multiple regression result shows that the quantity of mango tree owned is significantly and positively related to mango marketed supply at $1 \%$ significance level. It implies that a unit increases in mango tree increases its market supply by 0.416 quintals. This could be because as mango tree per household increases, it directly related to volume of mango production and increases marketable surplus.

Distance from nearest market: Distance to market was expected to adversely affect the volume of total sales. Accordingly, the result shows that distance to the market is negatively related with mango market supply at 5\% significance level. This implies that, a unit increase in walking hours from market center results in a decrease of mango market supply by 1.304 quintals. As the distance from the production area to market place become further and further, farmers supply the lesser quantity of mango to the market because of high transportation cost.

Age of the household head: The age of household head positively affects mango market supply at $1 \%$ significance level. An increase in age by one-year results in increasing mango market supply by 0.057 quintals. This implies that aged farmers would have a better experience and knowledge than younger farmers in agricultural activity. The reason is that, through time producers acquire experience about production and marketing and supply better than those who are less experienced.

Educational level of household head: Educational level of household head significantly and positively affects mango marketed supply. An increase in educational level by one-year results in an increase of mango marketed supply by 3.358 quintals at $1 \%$ significance level, other things remaining constant

Access to market information: Access to market information is positively related to mango 
market supply at $10 \%$ significance level. If a given producer has access to market information, mango marketed supply increases by 0.967 quintals. This might be because of mango producers who have behavior of searching price and production information from different sources such as neighbors, friends or Medias benefitted from mango marketing.

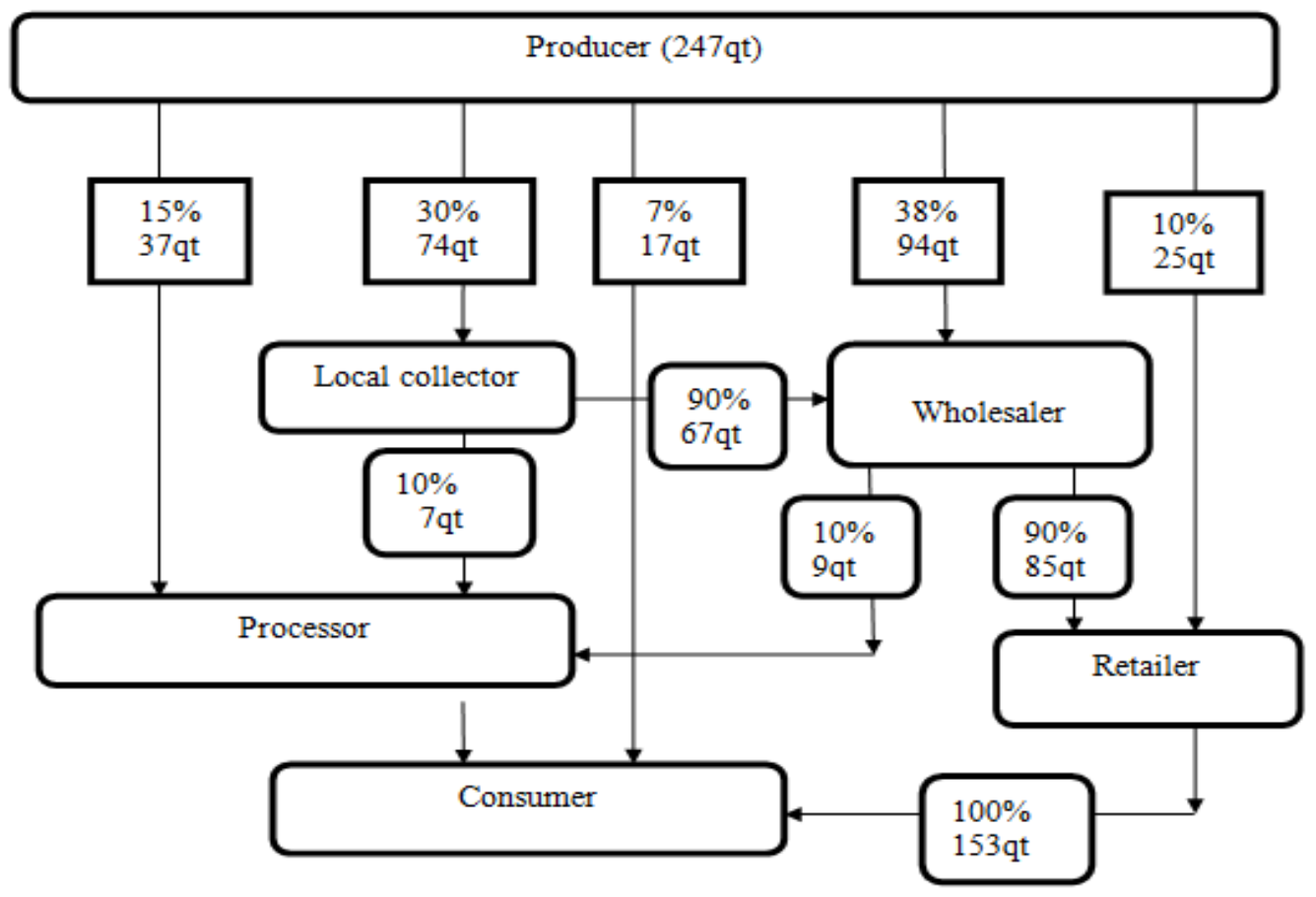

Figure1: Mango marketing channels

Source: Survey result, 2017

\section{Econometrics Model output}

More than $95 \%$ of mango producers in Gomma district are market participants. Therefore, Linear Regression Models were employed to identify factors affecting volume of mango market supply measured in quintals. For the parameter estimates to be efficient, unbiased and consistent assumptions of linear regression model should hold true. Hence, multicollinearity, and heteroscedasticity detection tests were performed using appropriate test statistics. The result for mean of VIF was 1.07. Therefore, Since VIF is less than 10, serious multicollinearity problems would not be suspected (Table 3).

Table 3 Result of variance inflecting factor for continuous variables

\begin{tabular}{lcc}
\hline \multicolumn{1}{c}{ Variable } & VIF & $1 / \mathrm{VIF}$ \\
\hline Education & 1.12 & 0.892857 \\
Age & 1.06 & 0.943396 \\
Family Size & 1.07 & 0.934579 \\
Distance from development agents & 1.08 & 0.925926 \\
Distance from the nearest market & 1.05 & 0.952381 \\
Quantity of mango tree owned & 1.06 & 0.943396 \\
Mean of VIF & 1.07 & \\
\hline
\end{tabular}


Table 4 Result of contingency coefficients for discrete variables

\begin{tabular}{lccccc}
\hline e(V) IMROVS D & Sex & Credit & Memb & Mktinfo & -cons \\
\hline Sex & 1.0000 & & & & \\
Credit & 0.1254 & 1.0000 & & & \\
Memb & 0.0753 & 0.0265 & 1.0000 & & \\
Mktinfo & 0.0235 & 0.0114 & 0.0538 & 1.0000 & \\
_cons & -0.4040 & -0.6183 & -0.3434 & -0.2381 & 1.0000
\end{tabular}

Breusch-pagan test was used to check for hetroscedasticity and the result showed that p- value of 0.09 indicating constant variance (Table 4).

Table 5 Heteroskedasticity test

Breusch-Pagan / Cook-Weisberg test for heteroscedasticity

Ho: Constant variance

Variables: fitted values of SUPPLY_AMOUNT

$\operatorname{chi} 2(1)=2.81$

Prob $>$ chi $2=0.0980$

After the appropriate tests, the OLS regressions

OLS estimation result, five variables were found to were run to identify the relationship between the independent and dependent variables. Based on the

influence mango market supply (Table 6).

Table 6 Factors affecting volume of mango market supply

\begin{tabular}{lccc}
\hline \multicolumn{1}{c}{ Variables } & Coefficients & SE & P-value \\
\hline Constant & -10.296 & 3.256 & .003 \\
Sex of household head & 1.346 & .525 & .124 \\
Education of household head & $3.358^{* * *}$ & .752 & .000 \\
Age of household head & $.057^{* * *}$ & .021 & .009 \\
Family Size & -.116 & .109 & .292 \\
Distance from development agents & .045 & .123 & .717 \\
Access to credit service & .687 & .604 & .261 \\
Membership in Cooperatives & .510 & .596 & .397 \\
Access to market information & $.967^{*}$ & .528 & .073 \\
Distance from the nearest market & $-1.304^{* *}$ & .576 & .028 \\
Quantity of mango tree owned & $.416^{* * *}$ & .101 & .000 \\
\hline
\end{tabular}

Dependent variable: mango supplied to market in quintals in 2016/2017. * Significant at 10 percent, ** Significant at 5 percent, and $* * *$ Significant at $1 \%, n=73, R^{2}=0.659$ Adjusted $R^{2}=0.572$.

Quantity of mango tree owned: The multiple regression result shows that the quantity of mango tree owned is significantly and positively related to mango marketed supply at $1 \%$ significance level. It implies that a unit increases in mango tree increases its market supply by 0.416 quintals. This could be because as mango tree per household increases, it directly related to volume of mango production and increases marketable surplus.

Distance from nearest market: Distance to market was expected to adversely affect the volume of total sales. Accordingly, the result shows that distance to the market is negatively related with mango market supply at 5\% significance level. This implies that, a unit increase in walking hours from market center results in a decrease of mango market supply by 1.304 quintals. As the distance from the production area to market place become further and further, farmers supply the lesser quantity of mango to the market because of high transportation cost. 
Age of the household head: The age of household head positively affects mango market supply at $1 \%$ significance level. An increase in age by one-year results in increasing mango market supply by 0.057 quintals. This implies that aged farmers would have a better experience and knowledge than younger farmers in agricultural activity. The reason is that, through time producers acquire experience about production and marketing and supply better than those who are less experienced.

Educational level of household head: Educational level of household head significantly and positively affects mango marketed supply. An increase in educational level by one-year results in an increase of mango marketed supply by 3.358 quintals at $1 \%$ significance level, other things remaining constant.

Access to market information: Access to market information is positively related to mango market supply at $10 \%$ significance level. If a given producer has access to market information, mango marketed supply increases by 0.967 quintals. This might be because of mango producers who have behavior of searching price and production information from different sources such as neighbors, friends or Medias benefitted from mango marketing.

\section{CONCLUSION}

The study was designed to analyze factors affecting mango market supply and identify the existing market channel in South West Ethiopia Gomma district. The data collected from mango producers was analyzed using both descriptive statistics and econometrics model. Ten independent variables have been regressed on the dependent variable. Accordingly, five independent variables namely educational level, age, access to market information and number of mango trees per household are positively related with mango market supply however, distance of producers' home from the nearest market center is negatively affected mango market supply.

Eight mango market channels have been identified in the study area. Among these channels, Producer $\rightarrow$ Retailer $\rightarrow$ Consumers channel was the most important and dominant mango market outlet through which producers and consumers get acceptable prices.
The study result indicates that educational level of household heads positively affected mango market supply. Households with formal education are in a better position in mango production and market supply. Therefore, provision of continuous training and adult education is highly recommended. Market information is another important factor that affects farmers' mango market supply. Households who have regular access to market information have better performance in mango market supply than their counterparts. Equipping smallholder farmers with necessary market infrastructure is recommendable if it is required to increase their market supply performance. Distance of households' residential home from the nearest rural market center is also important factor that hinders mango market supply as directly related with market transaction cost. Establishment of accessible market center is recommendable to increase market participation level of producers.

\section{REFERENCES}

Carlson, H.L., K.M. Klonsky, and P. Livingstion. 2008. Sample Costs to Produce Potatoes Fresh Market: Klamath Basin in the Intermountain Region. PO-IR-08-1, University of California Cooperative Extension.

CSA (Centeral Statistical Agency of Ethiopia) 2008. Summery and Statistical report of the 2007 Population and housing census. Addis Ababa, Ethiopia.

Davis, K. 2006. Farmer field Schools: A boom or bust for extension in Africa? Journal of International Agricultural and Extension Education 13(1), 91-97.

Green, W. H. 2003. Econometrics Analysis. $5^{\text {th }}$ edition, Prentice Hall. International, Inc.New York, USA. pp780-789.

Griesbach, J. 2003. Mango growing in Kenya. World Agroforestry Center (ICRAF). Nairobi,Kenya.

IFAD (International Fund for Agricultural Development) 2003. Promoting Market Access for the Rural Poor in order to achieve the millennium 
Development Goals. Discussion paper for the Twenty - Fifth Anniversary Session of IFAD's Governing Council. Rome, Italy.

IPMS (Improving Productivity and Marketing Success) 2007. Gomma Pilot Learning Woreda Diagnosis and Programm Design. Addis Ababa, Ethiopia P85.

Joonsten, F. 2007. Development Strategy for the Export-Oriented Horticulture in Ethiopia. Ethiopian horticultural Strategy. Retrieved from http://edepot.wur.nl/45238

Kasa, B. 2003. Agricultural Extension in Ethiopia; The case of participatory demonstration and training extension system. Journal of social development in Africa vol. 18 (1) P983

Lumpkin, T.A.,Weinberger, K. and Moor, S. 2005. Increasing Income through fruits and vegetable production opportunities and challenges. Draft Note for Consultative Group on International Agricultural Research Science Forum, CGAR Priorities: Science for the Poor. http://www.globalhort.org/downloads/pdf /forum-agm2005.pdf.

MoARD (Minstry of Agriculture and Rural Development). 2005. Vegetable and fruits production and Marketing Plan. Ministry of Agriculture and Rural Development Annual report Addis Ababa, Ethiopia.
Seifu, G. 2003. Status of commercial fruit production in Ethiopia. Ethiopian Agricultural Research Institution Addis Ababa, Ethiopia. http://publication.eiar.gov.et:8080/xml ui/bitstream/handle/123456789/2114/ Seifu\%20Gebre\%20Mariam.pdfAbby yy.pdf

Tiwari, R. Baghel, B.S. 2014. Effect of intercropping on plant and soil of Dashehari mango orchard under low productive environments. Asian Journal of Horticulture 9(2):439-442.

Tsegaye, D., Ahmed, A. and Dilnesaw, Z. 2009. Availability and Consumption of Fruits and Vegetables in Nine Regions of Ethiopia with Special Emphasis to Vitamin A Deficiency. Ethiopian Journal of Health Development, 23(3): 216-222.

World Bank Group. 2004. Developing Competitive Value Chain in Ethiopia. Retrieved from http://documents.worldbank.org/curated/e n/750101468751792291/pdf/383710Ethi opia1 value0chains0note029.pdf.

Yamane, T.1967. Statistics, An Introductory Analysis, $2^{\text {nd }}$ Ed., New York: Harper and Row.

Yeshitela, T.B. and Nessel, T. 2004. Characterization and Classification of Mango Ecotypes Grown in Eastern Hararghe (Ethiopia). Sarhad Journal of Agriculture, 19 (2):179-180 